\title{
How constrained? Entry into the French Atlantic fishery through second- hand vessel purchase
}

\author{
Ingrid E. van Putten ${ }^{\mathrm{a},{ }^{*}}$, Emmanuelle Quillérou ${ }^{\mathrm{b}}$, Olivier Guyader ${ }^{\mathrm{c}}$
}

\author{
${ }^{a}$ CSIRO Wealth from Oceans National Research Flagship, CSIRO Marine and Atmospheric Research, GPO Box \\ 1538, Hobart, Tasmania, 7001, AUSTRALIA \\ b United Nations University, Institute for Water, Environment and Health (UNU-INWEH), 175 Longwood Road \\ South, Suite 204, Hamilton, ON L8P 0A1, CANADA \\ c IFREMER - UMR_101 AMURE, Département d'économie maritime, Centre de Brest, BP 70, 29280 PLOUZANE \\ *: Corresponding author : Ingrid E. van Putten, email address : ingrid.vanputten@csiro.au \\ E. Quillérou, Emmanuelle.Quillerou@unu.edu \\ O. Guyader, Olivier.Guyader@ifremer.fr
}

\begin{abstract}
:
Over the past decades fisheries policies have been mainly aimed at encouraging capacity reduction in over-exploited fisheries. Correspondingly, research has focused on developing incentives to exit fisheries rather than investigating entry behaviour. However, with ageing and also fewer fishery participants, concern regarding sectoral renewal is increasing. The second-hand market is an important entry point for first-time owners because it potentially reduces capital constraints by supplying cheaper vessels than newly built ones. The aim of this study is to test whether new fishers entering the industry face greater capital constraints than fishers already in the industry, taking the second-hand market as our population of interest. We model new entry into the fishing sector using 18 years of French Atlantic fleet data with a logit model. We incorporate trade network variables and family connections indicative of the relationship and connections between market traders potentially reducing capital constraints. As expected, we find that first entry is more likely by younger owners for older and cheaper vessels. This suggests that first-time owners are more capital constrained than fishers already trading on the second-hand market. Capital constraints are reduced by geographical proximity and increased integration into a trading network.
\end{abstract}

\section{Highlights}

Renewal and entry in the fishing industry is an issue of growing importance. The second-hand market is an important entry point for capital constrained owners. First-time buyers of second-hand vessels are more capital constrained. Younger first-time owners are more likely to enter with older and cheaper vessels. Geographical proximity and trading network integration reduce capital constraints.

Keywords: Entry into fishery; network analysis; logit model; second-hand trade; market analysis; fishing vessels; French Atlantic fisheries 


\section{Introduction}

The French Atlantic fishery comprises a considerable fleet of 3,300 vessels that make up 70 percent of the overall French mainland fleet ${ }^{1}$. Most vessels in the French Atlantic fleet are trawlers, and like in many fisheries around the world, the size of the fleet has fallen in conjunction with decreased resource abundance. Over the past decades several management policies aimed at actively encouraging capacity reduction in the French fishing fleet have been implemented. The first of these policies was the introduction of a compulsory access licence for all fishing operations in France in 1988 (Decision 1.88 of the Comité Central des Pêches Maritimes of September 22, 1988). Access licences limit the total number of vessels operating in the fleet and the additional entry restrictions limit fleet power and tonnage. As the access rights are tied to the vessel, entry to the fishery could, from then on, only be gained through the purchase of a new or secondhand vessel. In addition, fisheries that faced reduced resource abundance are introducing fishing rights. Fishing rights are however not well documented in France as they are managed at the local level by producer organisations.

Since 1992, entry of new vessels into the fishery has been increasingly difficult. A new vessel can enter only if another vessel with greater capacity leaves the fleet, so that an overall set reduction in national fleet capacity can be achieved. For the purpose of reducing capacity, a series of decommissioning schemes were established from 1991 (Cueff 2004) mostly targeted at declining fisheries following the 2002 Common Fishery Policy Reform (Guyader, Berthou, and Daurès 2007). Decommissioning has been implemented continuously since 1991, with the rent created by the scheme captured in vessel prices. 
At the same time as the decommissioning scheme a seemingly contradictory policy to help fleet renewal was also implemented with the government offering some subsidies to construct new vessels (Mesnil 2008). However, this programme was conditional on meeting the overall capacity reduction target. Between 1992 and 2010, a total of 833 new vessels were constructed (with or without subsidy) for 1,891 scrapped vessels (with or without subsidy).

Overall, the size of the French Atlantic fleet was reduced by 35\% (1,736 vessels) between 1992 and 2010. Many fisheries have moved towards significantly smaller fishing fleets. In the French Atlantic fishery this is evidenced by the 34 percent decrease in the number of vessels less than 10 meters and 51 percent decrease for vessels over 40 meters. The smaller size fleet is characterised by increases in harvest and economic efficiency (Guyader et al. 2006). There are few new vessel constructions (with access rights) because of the limited entry system, but also because capital investments for new vessels are generally very high. This high capital demand could constitute a barrier to entry for more capital-constrained potential first-time owners into the fishery sector who are typically also younger.

Because of capital constraints and limited new vessel entry, second-hand vessel markets have become a crucial entry point for first-time owners to the French Atlantic fishery (Guyader et al. 2006). This was most obvious from 1996 to 2002 with an increase in the number of owners exchanging vessels on the second-hand market (Quillérou et al. 2011). Around 280 vessels were traded every year on the Atlantic second-hand vessel market between 1992 and 1995 rising to around 400 vessels a year between 1996 and 2001. In the latter period increasing prices per $\mathrm{kW}$ were also observed on the secondhand market. Greater profitability following reduction in the fleet numbers may have 
been a driver for these price increases ${ }^{2}$. Since 2002 both the number of vessels exchanged on the second-hand vessel market and the number of owners exchanging second-hand vessels have decreased. However, since 2002 the price per $\mathrm{kW}$ has doubled despite the reduction in the number of vessel exchanges taking place.

Trades in second-hand vessels are higher within defined geographical areas (Quillérou et al. 2011). Buyers and sellers find one another mostly through local information channels such as direct contact, through other fishers, newspapers, fishers associations, producer organisations, and accounting centres. Internet websites have recently become popular for advertising sales. Contrary to smaller vessels, bigger (more expensive) vessels tend to be traded through intermediaries (brokers) ${ }^{3}$. Although most trades are within certain geographic areas, there has been some redistribution of the fleet towards Aquitaine and Northern France over the time period considered (Quillérou, Roudaut, and Guyader in review).

Due to the importance of second-hand vessel markets to capital constrained first-time owners in different fisheries, these markets have been the subject of price formation investigation. Prices of second-hand vessels are the result of both demand and supply characteristics. Demand typically depends on the age of buyers and future profit expectations. Supply depends on level of natural, physical, human, immaterial capital investment, and depreciation.

To establish the relationship between supply and demand for second-hand vessels various econometric techniques have been applied to empirical vessel trade data. For instance, hedonic regressions, a revealed preference approach used to estimate demand on the basis of constituent characteristics of a good, has been used to determine how much second-hand vessel prices change with different vessel attributes such as length, 
age, and engine power, fleet segment, the type of hull and the maritime district of registration (e.g. Daurès et al. 2006; Kirkley and Squires 1988). Even though the second-hand vessel market is characterised by market segmentation (Tsolakis, Cridland, and Haralambides 2003; Quillérou et al. 2011), if the vessel price is sufficiently independent from supply-side variables, it could be used as proxy for buyer's capital constraints.

This paper is structured as follows. Section 2 details the materials and methods for logit estimation and social networks. Section 3 details our results which are discussed in Section 4 followed by our conclusions in section 5 .

\section{Materials and methods}

\subsection{Models of fisher entry}

As mentioned in the introduction, over the past decades much fisheries research has focussed on reducing fishing capacity for sustainability as well as economic reasons and entry into fisheries has largely been ignored. Some authors have indicated concern over the lack of focus on industry renewal, entry and investment, particularly in quota managed fisheries (Putten van and Gardner 2010). The theoretical literature and applied models of entry or investment behaviour make up only a small proportion of the fisher decision-making literature (Putten van et al. 2011). The models generally indicate that entry, stay, and exit decisions in open access fisheries are correlated to the profitability of the vessels (Ward and Sutinen 1994; Pradhan and Leung 2004; Mardle et al. 2006), the availability of technology, and technology uptake (Fissel and Gilbert 2010).

Entry decisions are sometimes seen as analogous to investment decisions. However, explanatory variables for entry decisions often explicitly include non-monetary drivers. 
Most entry and investment models have been theoretical in nature (Clark, Clarke, and Munro 1979; Boyce 1995; Sandal, Steinshamn, and Hoff 2007), but some applied investment models have shed light on how vessels might adjust their level of capital in response to changes in long term prices and stock conditions, assuming profit maximizing behaviour (Squires 1987; Asche et al. 2008; Nøstbakken 2008). Understanding of fisher investment behaviour is still considered low (Garcia and Grainger 2005) but this is slowly improving. A few studies outline that a range of fisher characteristics may affect observed entry (and exit) decisions (Anderson 1980; Smith 1981; Binkley 1995; Pollnac, Pomeroy, and Harkes 2001; Pollnac and Poggie 2006). Recent studies of micro-scale individual fishers investment decisions within a given firm however showed that production level, debt, interest rates and capital stocks are primary determinants of investments, and investment in vessels being governed by oneyear lagged variables (Nøstbakken forthcoming; Jensen, Andersen, and Jensen 2011). Tidd et al (2011) show that investment is affected by vessel age and size, future revenue, operating cost, stock status of the main target species, impact of management measures, and total fleet size (proxy for congestion). Between firm differences in investment levels is often linked to geographical location and whether it is a family operation (Nøstbakken forthcoming). Studies of economic models of investment and capacity development, however, remain scarce in practice (Nøstbakken, Thébaud, and Sørensen 2011).

Trade in the second-hand vessel market has the potential to reduce capital constraints faced by owners because second-hand vessels have lower prices compared to new vessels due to depreciation. Also, social networks exist in most markets (Uzzi 1996; Eguíluz and Zimmermann 2000; Podolny 2001; Jackson 2008). The presence of social 
or family connections between a young first-time buyer and the seller may decrease prices paid for fishing vessels compared to the market prices, or better vessel quality for the same price. For instance, fathers may charge their sons a price slightly less than the market price to help them enter the fishing sector. Also, working relationships such as between an owner and an existing crew member could reduce market prices paid because the buyer has perfect information when buying the vessel they are working on. Second-hand vessel trade with greater levels of kinship- or social networks may thus reduce capital constraints. On the other hand, capital constraint could increase due to increased demand in second-hand fishing vessels under limited entry. It is thus not theoretically clear that second-hand trade removes capital contraints on first-time owners completely.

In this current study we test whether first-time owners are effectively capital constrained compared to second-hand vessel buyers already in the fishery. We shift from dynamic models of entry and exit of vessels to focus on fisher entry. We focus on within-firm investment but not on-between firm investments. In particular, we focus on first-time fishery owners, who embody renewal of owners operating in the French Atlantic fishery and are hypothesised to high levels of capital constraints. These first entry owners represent the majority (about 90\%) of owner entries in the French Atlantic fleet whilst owners entering for the second time or more represent a minority (Quillérou and Guyader, 2012, Tables $2 \& 3$ ). This study is complementary to the description of the French fleet vessel and owner movements by Quillérou and Guyader (2012) and the study of second-hand market trade flows along the French coastline by Quillérou, Roudaut, and Guyader (in review). 
We develop a logit model using 20 years of second-hand vessel trade data. As a novel approach we supplement our entry model with indicators of the first-time owner's place in a vessel trade network and use network statistics as explanatory variables in our entry model. We hypothesize that the lack of integration into a second-hand trade network and increased capital constraint explain first time entry through the second-hand vessel market. By better understanding the potential role of trade networks and the capital constraints placed on first-time owners into the fishing sector through the second-hand vessel market, we can suggest policy reforms and alternative measures to encourage entry of fishers into the sector.

\subsection{Theory and methodology}

We use a utility maximisation framework to explain the economic behaviour of firsttime owners in the second-hand vessel market and consequently the French Atlantic fisheries. It is theorised that first-time second-hand vessel buyers seek to maximise utility with respect to entering the fishery. In our model the utility derived from entering the fishery through the second-hand vessel market can be explained by attributes of the vessel purchase, attributes specific to the individual decision maker, and their 'place' in the trade network.

A stochastic utility model of entry choice can be developed where the utility of the choice alternatives ( $i$ which run from $1-n)$ depend on the characteristics of the purchase and the attributes of the buyer $(k)$ including their place in the trade network. We apply a logit analysis to estimate the probability of $k$ choosing alternative $j$. The logistic distribution is given by (McFadden 1974):

$$
P_{j}^{k}=\frac{\exp \left[v^{k}\left(x^{j}\right)\right]}{\exp \left[v^{k}\left(x^{i}\right)\right]}
$$


The binary logit model predicts probabilities that fall between zero and one by using an S-shaped cumulative density function (CDF) to transform the dichotomous 0-1 dependent variable. The cumulative logistic probability function is specified as:

$$
P_{i}=\frac{1}{1+e^{-Z_{i}}}
$$

where $e$ is the base of natural logarithms and $Z_{i}=\alpha+\beta X, \alpha$ and $\beta$ are the estimated parameters of the logit model and $X$ is a vector of explanatory variables. The dependent variable in the regression equation is the natural logarithm of the odds that the secondhand vessel buyer is a first-time owner and the right hand side of the regression is linear in the parameters of the model.

Our model is developed using data available from Ifremer's Fisheries Information System (IFREMER 2010) including European fleet register data, vessel activity, and fleet segment. For the second-hand vessel transaction prices and owner and buyer information we use information for vessels registered in the French Atlantic from 1992 to 2010 . We estimate what determines the probability that an owner buying a vessel on the second-hand market is a first-time owner. We consider measures of capacity (vessel characteristics and fleet segments as proxy for gear), prices, network integration and family connections, and geographic region. Network integration refers to integration into the second-hand market: first-time owners are typically not integrated with integration increasing with the number of second-hand trade transactions for a given owner. Family connections refer to a shared family name between buyer and seller. In France, wives take the name of their husband as their family name and children take the last name of their father. Testing for trade based on common family names would capture father-son trades or trade between male cousins or uncle-nephew (or with 
unmarried fisherwomen). Information on working relationship connections between buyer and seller is not available and this type of buyer-seller connection is not included in our study. Regional and time dummies are included to control for spatial and time patterns in capital constraints. Depreciation is captured by vessel age and starts immediately because of the stochasticity of natural resource stock (Singh, Weninger, and Doyle 2006). All these determinants relate to the physical and some immaterial capital constraint on fishers for investment into means of production (as defined by Nøstbakken, Thébaud, and Sørensen 2011). Additionally, constant vessel prices can also capture some of capital constraint faced by fishers as shown in Daurès et al (2006) and Guyader, Berthou, and Daurès (2007). Capital constraint is typically greater for first entry owners. We thus assume greater capital constraints on first entry fishers for greater capacities and prices, lower network integration and no family connections to the seller. We use R (version 2.8.1) to format the data and perform simple statistical analyses, and use Systat (version 8.0) to develop our logit model.

As mentioned above, in our vector of explanatory variables we include statistical indicators of each first entry vessel buyers place in the trade network. We use a network analysis approach to calculate statistical indicators for each individual trader in the second-hand vessel market. Network analysis is an area of research originating in the biological sciences but made famous by analysis of human social systems (e.g. Milgram 1967). Network theory and associated analysis explains the characteristics of a system of connected individuals and the implications of these connections, providing insight into different social processes (e.g. Glaeser, Sacerdote, and Scheinkman 1996; Burk, Steglich, and Snijders 2007; Oetting and Donnermeyer 1998; Barabási et al. 2002). The connections between individuals (also referred to as actors or nodes) in a 
network can be many things including a market exchanges and trade (e.g. Cook and Whitmeyer 1992; Jackson 2008). Social networks where shown to affect trade in the Marseille fish market (Kirman 2001; Weisbuch, Kirman, and Herreiner 2000). When demand outstripped supply it was beneficial for a buyer to establish a relationship with just one (large) seller to ensure supply. At other times, when the catch was large and shopping around resulted in a better price, buyer loyalty to one particular seller was not so evident. Predictability was therefore central to the fish market's repeat relationships (Weisbuch, Kirman, and Herreiner 2000).

In our study we map the second-hand vessel trades between market participants for the French Atlantic fishing fleet. Statistical indicators for each market trader (Table 1) in the network are generated using Cytoscape (version 2.6.2). For instance, edge count (connectivity) indicates the number of connections of an individual to the rest of the network. The greater the value, the more connected an individual is.

$<<$ Table 1 approximately here $>>$

We include the statistical network indicators (Freeman 1979; Putten van, Hamon, and Gardner 2011; NetworkAnalyser 2009; Brandes 2001; Watts and Strogatz 1998; Barabási and Albert 1998), shown above, as it is theoretically recognised that social context is an important determinant of economic behaviour in markets (Fligstein and Dauter 2007). 'Social exchange theory', provides the theoretical foundation for social network analysis of markets. Social exchange theory focuses on phenomena that economic exchange theory treats as indeterminate, such as power relationships and equity (Cook and Emerson 1978). In traditional neoclassical 'economic exchange theory', markets are rational and perfectly competitive, which means that exchange partners have no commitment to each other. However, often a variety of observed 
phenomena cannot easily be explained by simply applying the principles of 'economic exchange theory' (Jackson 2008). Since Granovetter (1985) many studies have looked at the moderating effect of relationships among agents in market exchanges (Rauch and Hamilton 2001) and used social exchange theory to help predict the effect of loyalties or longitudinal commitments on market exchanges (Cook and Emerson 1978; Myers and Shultz 1951; Rees and Shultz 1970; Kim 2009; Katz and Lazarsfeld 1955). Social and ethnographic patterns in fisheries suggest that tight social networks exist (e.g. Gatewood 1984; Palmer 1991). 'Social exchange theory' predicts that these social networks may extend to influence trade in associated markets.

\subsection{Data}

A general description of the French Atlantic fishery fleet and owners can be found in Quillérou and Guyader (2012). As the access licence in this fleet is tied to the vessel, we are able to model fishery entry by virtue of vessel trade data. A total number of 4,238 second-hand vessels were traded between 1992 and 2010. There were 4,923 individuals who participated in the second-hand vessel trade ${ }^{4}$. Consistent with the findings of Quillérou et al (2011), three relatively distinct time periods between 1992 and 2010 can be identified, each characterised by either a policy change or other significant external event. For instance, between 1992 and 1997 the fisheries are recovering from the 1993 "fishing crisis" (Mesnil 2008). In the next period (between 1998 and 2004) we observe the surge in confidence after the fishing crisis. This period is characterised by an increase in average second-hand vessel prices (Figure 1). The last period between 2005 and 2010 is characterised by a downward trend in prices and a decrease in the number of exchanges on the second-hand market, especially for vessels over 18 meters.

$<$ Figure 1 approximately here $>$ 
The average transaction value between 1992 and 2010 was $€ 144,199$ (median €76,747) per second-hand vessel, and the average price per engine power was $€ 932.77 / \mathrm{kW}$ (median $€ 957.62)^{5}$. The average value of traded vessels starts to rise around 2001 and peaks around 2004 increasing by more than $50 \%$.

There are more small vessels than larger vessels traded, which is consistent with the fleet composition (14\% of the Atlantic fleet is made of vessels longer than 18 meters). The patterns for larger vessels (longer than 18 meters), that make up 7.3 percent of the total trade (308), is a little different. After an initial decline in second-hand vessel value after 1992, there was a subsequent but temporary increase of the value of larger vessels, declining again to 1992 levels by 2010. As expected, the average price at which these larger vessels are traded is significantly higher (average $€ 504,830$, median $€ 495,136$ ). Vessel sale prices are a function of vessel length and engine power (see Daurès et al. 2006) ${ }^{6}$. However, for vessels longer than 18 meters this relationship is not so obvious, with a correlation of 0.3421 between price and vessels length and 0.4168 between price and engine power. This is because bigger vessels have become less profitable (rising fuel costs and decreases in fish stocks). The average age of traded vessels has increased in a linear fashion (at 5.6\% per annum, $\mathrm{R}^{2}=0.948$ ) and buyers of second-hand vessels are now paying relatively more than before for older vessels, a result also found in other studies (Adland and Koekebakker 2007; Quillérou et al. 2011). This suggests that rising costs and lower harvests have been offset by the decrease in overcapacity making individual vessels more profitable.

Besides information on the sale price and vessel characteristics we also have information on the buyers and sellers which shows that trade is mainly concentrated in South and North Bretagne ( $45 \%$ of all trade) ${ }^{7}$. The majority of second-hand vessel trade 
$(66 \%)$ is between buyers and seller registered in the same region ${ }^{8}$. As a group, traders in second-hand vessels are getting older by 0.381 years per annum $\left(\mathrm{R}^{2}=0.859\right)$ on average. As expected, the buyers of second-hand vessels are younger than the sellers by an average of 6.61 years ${ }^{9}$.

There is little regional variation in the proportion of first entry buyers in relation to the total number of traders in the respective regions ${ }^{10}$. The number of first entry buyers varies between 44 in 2010 and 171 in 1997 and appears to be an exponentially declining $\left(y=178.49 e^{-0.0447 x}, R^{2}=0.5296, n=2,277\right)$. The decline in first entry buyers seems to be at an even faster rate in the trade in large vessel $\left(y=23.551 \mathrm{e}^{-0.0899 x}, \mathrm{R}^{2}=0.5867, \mathrm{n}=210\right)$. Even though there are relatively few fishers in the younger age bracket of up to 30 years (making up $12 \%$ of the total), they are more active participants in second-hand vessel trade as a higher proportion of these individual in this age bracket not only buy vessels but later also sell them and buy new ones again. Also, fishers have to retire by law when they are 54 years old.

We use the following variables in the first-time fisher entry model through purchase of second-hand vessels for the French Atlantic fisheries (Table 2).

$<<$ Table 2 approximately here $>>$

These variables have been chosen as available proxies of capital levels and values.

We also enter network statistics for all individuals who buy second-hand vessels between 1992 and 2010 as independent variables in our model (Table 3).

$<<$ Table 3 approximately here $>>$ 


\section{Results}

We use a stepwise process (Systat 8.0) to determine the significant variables in our firsttime entry model. The first-time entry model is significant at the 5\% level and entry behaviour can be explained by a combination of buyer, geographic, vessel, price, and trade network variables (Table 4).

$<<$ Table 4 approximately here $>>$

McFadden's Rho-Squared, a transformation of the LR statistic intended to mimic an Rsquared, is 0.370 . A value between 0.20 and 0.40 is considered satisfactory (Hensher and Johnson 1981). The model correctly predicts 71.9 percent of the first-time entry choices in the second-hand vessel market. Of the cases where first-time entry is made $73.4 \%(1,566)$ are predicted correctly. Of those cases where there is no first-time entry, $70.2 \%(1,338)$ are predicted correctly ${ }^{11}$.

The success indicator signifies the improvement the model shows over a purely random model that assigned the same probability of first-time entry in the second-hand vessel market to every observation in the data. The model produces a gain of 0.205 over the random model for responses and 0.230 for reference cases. The odds of the response are given by $\mathrm{p} /(1-\mathrm{p})$, where $\mathrm{p}$ is the probability of response, and the odds ratio is the multiplicative factor by which the odds change when the independent variable increases by one unit. For example, the buyer and seller being in the same geographic (B_S_SAME_REG) region increases the odds of a first-time entry into the second-hand vessel market by multiplicative factor of 1.545 , with lower and upper confidence bounds of 1.297 and 1.840 respectively. 
Consistent with expectations, the probability that the owner enters into the fishing sector for the first-time significantly decreases with lower owner age (B_AGE) and with less time spent in the industry (B_YRININDUST). Older fishers who have been in the industry for longer are less likely to enter for the first-time in the fishing sector with a second-hand vessel. We also tested for the influence of family relationships i.e. $o$ whether buyer and seller share the same last name (B_FAM_TRADE). Contrary to prior expectations; family relations did not have a significant effect on first-time entry. The characteristics of the seller of the vessels, for instance the fact that they were exiting the fishery (S_PERM-EXIT), did not have any explanatory power in our model ${ }^{12}$.

First-time owners are more likely to purchase an older vessel (VESSEL_AGE) for a lower price (PR_EUR000_DE). The horsepower of the vessel (VESSEL_kW) was not significant in our model and did not explain first entry into the fishery. The probability of entering the fishery increases if the buyer is in North Bretagne and decreases if the buyer is in Aquitaine or Pays de la Loire.

Three of the seven network statistics were significant in explaining first-time entry into the French Atlantic fisheries through purchase of a second-hand vessel. As expected, first-time owners had lower closeness centrality (B_NW_ClC), eccentricity (B_NW_ECC), and edge count (B_NW_EDG). All network statistics significant in our model indicate that first-time owners are less connected and less 'embedded' in the trade network for second-hand vessels. The inclusion of network statistics improved the predictive accuracy of our model with a McFadden's Rho-Squared of 0.177 without network statistics. 


\section{Discussion}

Our model shows that first-time owners pay significantly lower prices for the secondhand vessels they purchase. This suggests that capital constraints exist for first entry fishers in the Atlantic fishery and that capital is therefore not perfectly malleable (Clark, Clarke, and Munro 1979; Boyce 1995).

Contrary to prior expectations, capital constraints for first-time owners are not significantly reduced by the first-time owner's family connections to the seller. Moreover, our model suggests that the first-time owner's connections in the market place for second-hand vessels have a significant effect on the probability of entry. Firsttime owners do not seem strongly included in a vessel trade network when they enter the fishing sector in contrast to other buyers. This is consistent with the development in time of a personal social network (Lorenz 2000; Knoke and Kuklinski 1991). The lack of trade connections for first-time owners, as determined by the network variables included in our model, also indicate no significant reduction in capital constraints. Firsttime owners are however more likely to buy a vessel from a seller who is resident in the same region. This suggests that first-time entry of owners occurs through access to more information at the more local level rather than by means of integration into a trading network or explicitly through family connections.

Like any other capital investment fishing vessels are subject to depreciation. Secondhand vessels are therefore, on the whole, lower priced than new vessels. Cheaper second-hand vessels are an important point of entry into a fishery. This is particularly true as our study shows that first-time owners are typically younger and are more restricted in obtaining investment capital. As illustrated, first-time owners are more 
likely to purchase older (cheaper) vessels. This typically reflects the lower potential access to capital and investment opportunities of first-time owners (Martin et al. 2005).

There are some regional implications from the characteristics of second-hand vessel trades and consequent industry renewal. Our model shows that renewal in the French Atlantic fishery tends to be concentrated in one particular region, which is North Bretagne. This result is confirmed by Quillérou, Guyader et al. (2011) and Quillérou, Roudaut, and Guyader (in review) suggesting both vessel and owner renewal in this region through the operation of the second-hand vessel market. North Bretagne is also the most profitable fishing region (Le Floch et al. 2008; Martin et al. 2005) and is an area that obviously attracts first-time owners who bring second-hand vessels into the area that they may have purchased elsewhere. Also, Bretagne has historically been associated with small fishing vessels and small fishing harbours. This image is still very strong in the public mind. The region has thus set up policies to actively encourage sector renewal. This is most prominent in North Bretagne as South Bretagne has developed other economic activities (e.g. recreational boating). There are fewer firsttime owners in Aquitaine and Pays de la Loire which are both to the South of Bretagne. Even though Aquitaine is a region that attracts second-hand fishing vessels (Quillérou et al. 2011) and is a profitable fishing region, it tends to favour higher levels of foreign (Spanish) investment into the French vessels rather than entry of first-time owners into the sector $^{13}$.

Fisheries organisations and government institutions have suggested that financial support to buy vessels could help new owners to enter the fishing industry. Our findings that first-time owners are capital constrained suggest that this policy initiative should assist in achieving industry renewal. This would be particularly important in small scale 
fishery communities which are highly dependent on fishing and with limited alternative economic activities (Commission of the European Communities 2009, section 5.1; European Commission 2011, sections $2.2 \&$ 2.3). Targeted subsidies for first-time vessel buyers could be established as part of the 2013 European Union Fishery Policy reform. Alternatively, subsidies could help set up (formal or informal) forums that support increased interaction between second-hand vessel buyers and sellers, facilitate first-time owners integration into the network, and thus decrease capital constraints for first-time buyers. However, removing decommissioning subsidies might be more costeffective in terms of public spending than subsidising first-time owners because of the reduction in the rent captured from decommissioning schemes (Guyader, Berthou, and Daurès 2007).

\section{Conclusions}

Fisheries research in the past decades has focused mainly on developing incentives and management approaches to reduce fishing capacity. Increasingly, concerns are raised in relation to a lack of renewal in the fishing sector of both vessels and owners. It is suggested that capital investment including fishing vessels purchase, or quota in the case of ITQ managed fisheries, is perceived to be prohibitively high and discouraging first-time owners into fisheries.

We find evidence that first-time owners buying vessels on the second-hand market for entry in the fishing sector are more capital constrained than fishers already trading on the second-hand market. Capital constraints are reduced by geographical proximity and increased integration into a trading network. Access to information on vessels and fishing is key in the decision to enter the fishing sector for the first time. 
Financial support to buy vessels could help new owners to enter the fishing industry. Financial support for set up of (formal or informal) forums that support increased interaction between second-hand vessel buyers and sellers and facilitate first-time owners integration into the network could also help reduce the capital constraint of firsttime buyers. However, removing decommissioning subsidies might be more costeffective in terms of public spending than subsidising first-time owners. Removing these decommissioning subsidies removes the rent from decommissioning schemes captured into second-hand market prices. Removing these price distortions would therefore be more economically efficient as well as help first-time buyers buy their first fishing vessel.

One of the limitations of this study is that we do not have information about the actual relationship between first-time owners and the sellers of vessels other than through second-hand market trade. Although we do know that kinship relations did not explain first-time entry into the second-hand vessel market in our model some other relationships could exist that are not captured here, for example between a former crew member and an existing owner. Extending this current research and to map the effects of the largely unknown 'working relationships' in vessel trades, will be necessary to fully understand renewal in fisheries.

\section{Acknowledgements}

We are grateful to the three anonymous reviewers for their constructive suggestions. We would like to thank Dr Katia Frangoudes, Dr Rémi Mongruel and the rest of the AMURE team for their critical insights into French fisheries, as well as Michèle 
Jézéquel and Samuel Le Blond for sharing their extensive knowledge of Ifremer's databases and data with us. 


\section{References}

Adland, R., and S. Koekebakker. 2007. Ship valuation using cross-sectional sales data: A multivariate non-parametric approach. Maritime Economics \& Logistics 9:105-118.

Anderson, L. G. 1980. Necessary components of economic surplus in fisheries economics. Canadian Journal of Fisheries and Aquatic Science 37:858-870.

Asche, F., H. Eggert, E. Gudmundsson, A. Hoff, and S. Pascoe. 2008. Fisher's behaviour with individual vessel quotas--Over-capacity and potential rent: Five case studies. Marine Policy 32:920-927.

Barabási, A.L., and R. Albert. 1998. Emergence of scaling in random networks. Science 286:509-512.

Barabási, A.L., H. Jeong, Z. Néda, N E. Ravasz, A. Schubert, and T. Vicsek. 2002. Evolution of the social network of scientific collaborations. Physica 311:590 614.

Binkley, M. 1995. Risks, Dangers and Rewards in the Nova Scotia Offshore Fishery. Montreal: McGill-Queen's University Press.

Boyce, J. R. 1995. Optimal capital accumulation in a fishery: A nonlinear irreversible investment model. Journal of Environmental Economics and Management 28:324-339.

Brandes, U. 2001. A faster algorithm for betweenness centrality. Journal of Mathematical Sociology 25:163-177.

Burk, W. J., C. E. G. Steglich, and T. A. B. Snijders. 2007. Beyond dyadic interdependence: Actor-oriented models for co-evolving social networks and individual behaviors. International Journal of Behavioral Development 31 (4):397-404.

Clark, C. W., F. H. Clarke, and G. R. Munro. 1979. The optimal exploitation of renewable resource stocks: problems of irreversible investment. Econometrica: Journal of the Econometric Society:25-47.

Commission of the European Communities. 2009. Green Paper Reform of the Common Fisheries Policy. Brussels: European Commission.

Cook, K. S., and R. M. Emerson. 1978. Power, Equity and Commitment in Exchange Networks. American Sociological Review 43 (October):721-739.

Cook, K. S., and J. M. Whitmeyer. 1992. Two approaches to social structure: Exchange theory and network analysis. Annual Review of Sociology 18:109-127.

Cueff, J. 2004. A Case Study of Fishing Vessel Capacity Management Public Buyout Schemes: Community Experience through the Multi-Annual Guidance Programmes and Ways Forward. In Fisheries buybacks, edited by R. E. Curtis and D. Squires. Ames, Iowa, USA: Blackwell Publishing.

Daurès, F., J. Bihel, O. Guyader, P. Le Floch'h, N. Roudaut, C. Brigaudeau, O. Thebaud, and M. Jézéquel. 2006. Estimating capital value and depreciation of fishing fleets: application to French fisheries. In IIFET 2006 Conference. Montpellier, France.

Eguíluz, V. M., and M. G. Zimmermann. 2000. Transmission of Information and Herd Behavior: An Application to Financial Markets. Physical Review Letters 85 (26):5659-5662.

European Commission. 2011. Reform of the Common Fisheries Policy, Communication from the commission to the European Parliament, the Council, the European 
Economic and Social Committee and the Committee of the Regions. Brussels: European Commission.

Fissel, B. E., and B. Gilbert. 2010. Exogenous Productivity Shocks and Capital Investment in Common-pool Resources. http://www.pravdasurf.com/OccasionalFiles/Occasional\%20Papers/Eggs/Fissel. pdf.

Fligstein, N., and L. Dauter. 2007. The sociology of markets. Annual Review of Sociology 33 (1):105-128.

Freeman, L. 1979. Centrality in social networks: ii. Experimental results. Social Networks 2 (2):215-239.

Garcia, S., and R Grainger. 2005. Gloom and doom? The future of marine capture fisheries. Philosophical Transactions of the Royal Society B: Biological Sciences 360:25.

Gatewood, J. 1984. Cooperation, competition, and synergy: Information-sharing groups among southeast Alaskan salmon seiners. American Ethnologist 11 (2):350-370.

Glaeser, E., B. Sacerdote, and J. Scheinkman. 1996. Crime and social interaction. Quarterly Journal of Economics 111 (2):507-548.

Granovetter, M. 1985. Economic Action and Social Structure: The Problem of Embeddedness. American Journal of Sociology 91 (3):481-510.

Guyader, O., P. Berthou, and F. Daurès. 2007. Decommisioning schemes and capacity adjustement : A preliminary analysis if the French experience. In Fisheries Buybacks, edited by R. Curtis and D. Squires: Blackwell Publishing.

Guyader, O., F. Daurès, M. Jézequel, and O. Thébaud. 2006. Second Hand Market for fishing vessels and implicit price of fishing rights. In International Workshop on Regulating Access to Marine Fisheries in the Coastal Zone. IUEM, Plouzané

Hensher, D. A., and L. W. Johnson. 1981. Applied discrete-choice modelling. London: Croom Helm.

IFREMER. 2010. Système d'Informations Halieutiques (SIH). http://www.ifremer.fr/sih/.

Jackson, M. O. 2008. Social and economic networks: Princeton University Press.

Jensen, F., J. Andersen, and C. L. Jensen. 2011. Investment behaviour in individual nontransferable quota systems. Applied Economics 44 (8):969-978.

Katz, E., and P. F. Lazarsfeld. 1955. Personal Influence: The Part Played by People in the Flow of Mass Communication. New York: Free Press.

Kim, H. H. 2009. Networks, information transfer, and status conferral: The role of social capital in income stratification among lawyers. The Sociological Quarterly 50 (1):61-87.

Kirkley, J., and D. Squires. 1988. A limited information approach for determining capital stock and investment in a fishery. Fishery Bulletin 86 (2).

Kirman, A. P. 2001. Market organization and individual behaviour: Evidence from fish markets. In Networks and markets, edited by J. Rauch and A. Cassella. New York: Russel Sage Foundation.

Knoke, D., and J. H. Kuklinski. 1991. Network analysis: Basic concepts. In Markets, hierarchies and networks: The coordination of social life, edited by G. Thompson, J. Frances, R. Levačić and J. Mitchell. London: SAGE Publications Ltd. 
Le Floch, P., O. Thébaud, J. Boncoeur, F. Daurès, and O. Guyader. 2008. Une évaluation des performances économiques de la pêche côtière : le cas de la région Bretagne. Revue d'Economie Régionale et Urbaine 5:753-771.

Lorenz, E. H. 2000. Neither friends nor strangers: Informal networks of subcontracting in French industries. In Markets, hierarchies and networks: The coordination of social life, edited by G. Thompson, J. Frances, R. Levačić and J. Mitchell. London: SAGE Publications Ltd.

Mardle, S., O. Thébaud, O. Guyader, T. Hutton, R. Prellezo, and M. Travers. 2006. Empirical analysis of fishing fleet dynamics: entry, stay and exit choices in selected fisheries. In Bioecon conference. Cambridge, UK.

Martin, A., P. Le Floch, G. Le Lec, and J. Boncoeur. 2005. Résultats économiques des flottilles artisanales bretonnes: une vue synthétique à partir des données de l'observatoire économique régional des pêches. In Les revenus à la pêche, edited by J. Boncoeur: AMURE Working document R-06-2005.

McFadden, D. 1974. Conditional logit analysis of qualitative choice behaviour. In Frontiers in econometrics, edited by P. Zarembka. New York: Academic Press.

Mesnil, B. 2008. Public-aided crises in the French fishing sector. Ocean \& Coastal Management 51:689-700. . 2008. Public-aided crises in the French fishing sector. Ocean \& Coastal Management 51 (10):689-700.

Milgram, S. 1967. The small world problem. Psychology Today 1 (1):60-67.

Myers, C. A., and G. P. Shultz. 1951. The dynamics of a labor market. New York: Prentice-Hall.

NetworkAnalyser. 2009. NetworkAnalyser Help. http://med.bioinf.mpiinf.mpg.de/netanalyzer/help/2.6.1/index.html\#settings.

Nøstbakken, L. 2008. Fisheries law enforcement-A survey of the economic literature. Marine Policy 32:293-300.

- forthcoming. Investment Drivers in a Fishery with Tradable Quotas. Land Economics.

Nøstbakken, L., O. Thébaud, and L.C. Sørensen. 2011. Investment Behaviour and Capacity Adjustment in Fisheries: A Survey of the Literature. Marine Resource Economics 26 (2):95-117.

Oetting, E. R., and J. F. Donnermeyer. 1998. Primary Socialization Theory: the Etiology of Drug Use and Deviance. Substance Use and Misuse 33:995-1026.

Palmer, C.T. 1991. Kin-selection, reciprocal altruism, and information sharing among Maine Lobstermen. Ethology and Sociobiology 12:221-235.

Podolny, J. 2001. Networks as Pipes and Prisms of the Market. American Journal of Sociology 107 (1):33-60.

Pollnac, R. B., and J. J. Poggie. 2006. Job satisfaction in the fishery in two Southeast Alaskan towns. Human Organization 65 (3):329-339.

Pollnac, R. B., R. S. Pomeroy, and I. H. T. Harkes. 2001. Fishery policy and job satisfaction in three southeast Asian fisheries. Ocean and Coastal Management 44:531-544.

Pradhan, N. C., and P. S. Leung. 2004. Modeling trip choice behavior of the longline fishers in Hawaii. Fisheries Research 68 (1-3):209-224.

Putten van, E. I., K.G. Hamon, and C. Gardner. 2011. Network analysis of a rock lobster quota lease market. Fisheries Research 107:122-130. 
Putten van, E. I., S. Kulmala, O. Thebaud, N. Dowling, K.G. Hamon, T. Hutton, and S. Pascoe. 2011. Theories and behavioural drivers underlying fleet dynamics models. Fish and Fisheries.

Putten van, E.I., and C. Gardner. 2010. Lease quota fishing in a changing rock lobster industry. Marine Policy 34:859-867.

Quillérou, E., and O. Guyader. 2012. What Is Behind Fleet Evolution: A Framework for Flow Analysis and Application to the French Atlantic Fleet. ICES Journal of Marine Science: Journal du Conseil 69:1069-1077.

Quillérou, E., O. Guyader, F. Daurès, M. Jézéquel, E. Leblond, S. Le Blond, and M. Merzéréaud. 2011. Analyse statistique du fonctionnement du marché des navires d'occasion et de la dynamique associée des flottilles. Évolution des prix sur le marché des navires d'occasion de 1992 à 2008.

Quillérou, E., N. Roudaut, and O. Guyader. in review. Managing fleet capacity: national policies and regional market redistribution. Journal of Agricultural Economics.

Rauch, J. E., and G. G. Hamilton. 2001. Networks and markets: Concepts for bridging disciplines, in Networks and markets, edited by J. E. Rauch and A. Casella. New York: Russell Sage Foundation.

Rees, A., and G. P. Shultz. 1970. Workers in an urban labor market. Chicago: University of Chicago Press.

Sandal, L. K., S. I. Steinshamn, and A. Hoff. 2007. Irreversible Investments Revisited. Marine Resource Economics 22 (3):255-266.

Singh, R., Q. Weninger, and M. Doyle. 2006. Fisheries management with stock growth uncertainty and costly capital adjustment. Journal of Environmental Economics and Management 52 (2): 582-599.

Smith, C. L. 1981. Satisfaction bonus from salmon fishing: Implications for management. Land economics 57:181-196.

Squires, D. 1987. Long run profit functions of multiproduct firms. American Journal of Agricultural Economics 69:558-569.

Tidd, A. N., T. Hutton, L. T. Kell, and G. Padda. 2011. Exit and entry of fishing vessels: an evaluation of factors affecting investment decisions in the North Sea English beam trawl fleet. ICES Journal of Marine Science: Journal du Conseil 68 (5):961-971.

Tsolakis, S.D., C. Cridland, and H.E. Haralambides. 2003. Econometric modelling of second-hand ship prices. Maritime Economics \& Logistics 5 (347-377).

Uzzi, B. 1996. The sources and consequences of embeddedness for the economic performance of organizations: The network effect. American Sociological Review 61:674-698.

Ward, J. M, and J. G. Sutinen. 1994. Vessel entry-exit behaviour in the Gulf of Mexico shrimp fishery. American Journal of Agricultural Economics 76 (4): 916-923.

Watts, D. J., and S. Strogatz. 1998. Collective dynamics of small world networks. Nature 393:440-442.

Weisbuch, G., A. Kirman, and D. Herreiner. 2000. Market organization. Economica 110:411-436. 
${ }^{1}$ The French mainland fleet includes vessels registered on the Atlantic Ocean or Mediterranean Sea including Corsica but excluding the French overseas territories.

${ }^{2}$ Causal relationships are difficult to derive here.

${ }^{3}$ It is not possible to quantify this more specifically because of the lack of specific data.

${ }^{4}$ The number of participants is greater than the number of trade interactions because if the trade is simply between two people, this is counted as one trade interaction and two trade participants.

${ }^{5}$ All values are in Euro and have been deflated to 2010 values.

${ }^{6}$ The correlation is 0.7561 between price and length and 0.7613 between price and engine power. Obviously there is also a relationship between length and engine power (correlation of 0.9211 for all vessels and 0.7332 for larger vessels).

${ }^{7}$ Some geographic information prior to 2004 is missing.

${ }^{8}$ There is a slight overestimation as some buyers are also sellers of second-hand vessels in subsequent years.

${ }^{9}$ Correlation between the average age of sellers and buyers time series is 0.867 .

${ }^{10}$ We find that for vessels greater than 18 meters there are a relatively higher number of first entry buyers ( $0.68 \%$ as opposed to $0.54 \%$ of the total number of buyers) but in terms of age distribution these buyers of larger vessels do not appear different to the overall sample.

${ }^{11}$ This includes where an owner enters the market for a second (or more) time.

${ }^{12}$ None of the seller characteristics, such as seller age and time in the fishery, were significant at the 5 percent level.

${ }^{13}$ New owners might enter into the Aquitaine fishing sector by buying newly built fishing vessels, but this would need to be tested separately. 


\section{Highlights}

- Renewal and entry in the fishing industry is an issue of growing importance

- The second-hand market is an important entry point for capital constrained owners

- First-time buyers of second-hand vessels are more capital constrained

- Younger first-time owners are more likely to enter with older and cheaper vessels

- Geographical proximity and trading network integration reduce capital constraints 
Figure 1. Index of average annual value of second-hand vessels traded (€/kW) for all vessels and for vessels greater than 18 meters between 1992 and 2010 for the French Atlantic fishery. 


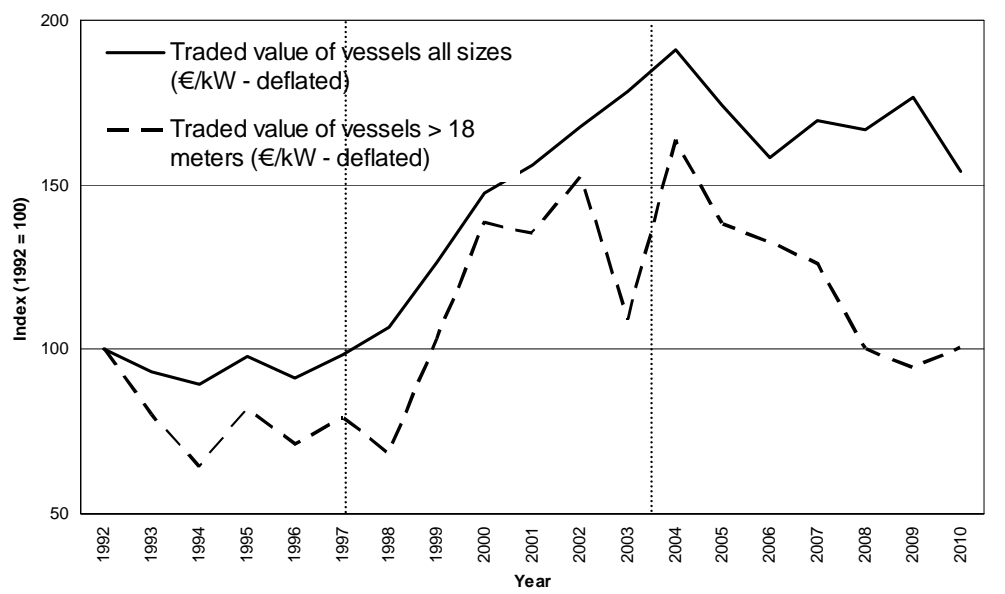




\section{Table 1}

Statistical indicators for network structure, dynamics and node characteristics.

\begin{tabular}{|c|c|c|}
\hline $\begin{array}{l}\text { Statistical indicator* } \\
\text { (variable name) }\end{array}$ & Description & Definition \\
\hline $\begin{array}{l}\text { Closeness centrality } \\
\left(\mathrm{B} \_\mathrm{NW} \_\mathrm{ClC}\right)\end{array}$ & $\begin{array}{l}\text { the distance of a node to all other nodes } \\
\text { in the network. } \\
\text { Nodes with high closeness centrality } \\
\text { may have few connections, yet the } \\
\text { pattern of their direct and indirect ties } \\
\text { allows them to access all the nodes in } \\
\text { the network relatively quickly. }\end{array}$ & $C_{c}(n)=1 / \operatorname{avg}(L(n, m))$ \\
\hline $\begin{array}{l}\text { Clustering coefficient } \\
\text { (B_NW_CC) }\end{array}$ & $\begin{array}{l}\text { probability that two nearest neighbours } \\
\text { of a particular node are also the nearest } \\
\text { neighbours of each other }\end{array}$ & $\begin{array}{l}\text { Average for all nodes } n \text { with } k \\
\text { neighbours for } k=2, \ldots\end{array}$ \\
\hline $\begin{array}{l}\text { Eccentricity } \\
\text { (B_NW_ECC) }\end{array}$ & $\begin{array}{l}\text { The largest geodesic distance between a } \\
\text { node and any other nodes }\end{array}$ & $\operatorname{Max} L(n, m)$ \\
\hline $\begin{array}{l}\text { Edge count / } \\
\text { connectivity } \\
\text { (B_NW_EDG) }\end{array}$ & The node's number of neighbours & $k$ \\
\hline $\begin{array}{l}\text { Node degree } \\
\text { distribution } \\
\text { (B_NW_InD) } \\
\text { (B_NW_OutD) }\end{array}$ & $\begin{array}{l}\text { Probability that a node in the network is } \\
\text { connected to } \mathrm{k} \text { other nodes }\end{array}$ & $\begin{array}{l}P(k) \sim k^{-\gamma} \\
n=\text { node } \\
k_{n}=\text { number of edges coming in } \\
\text { and linked to } n \text { (in-degree) and } \\
\text { number of edges going out (out- } \\
\text { degree) in directed network }\end{array}$ \\
\hline $\begin{array}{l}\text { Neighbourhood } \\
\text { connectivity } \\
\text { (B_NW_NHCon) }\end{array}$ & $\begin{array}{l}\text { The extent to which a node shares } \\
\text { neighbour with other nodes }\end{array}$ & $T_{n}=\operatorname{avg}(J(n, m)) / k_{n}$ \\
\hline
\end{tabular}


* based on (Putten van, Hamon, and Gardner 2011; NetworkAnalyser 2009; Brandes 2001; Freeman 1979; Watts and Strogatz 1998; Barabási and Albert 1998) 
Table 2

Independent variables names and descriptions for the entry model.

\begin{tabular}{|c|c|c|c|c|c|}
\hline Variable name & Description & $\mathbf{N}$ & Coding & $\begin{array}{l}\text { Sample } \\
\text { mean* }\end{array}$ & SD \\
\hline $\mathrm{B} 1_{-}^{\mathrm{st}}{ }_{-}^{\mathrm{st}}$ entry & $\begin{array}{l}\text { Buyer is first time entrant to } \\
\text { the fishery }\end{array}$ & 4238 & $\begin{array}{l}1=\text { yes, } \\
0=\text { no }\end{array}$ & 0.537 & \\
\hline B_YRSINDUST & $\begin{array}{l}\text { Years in marine industry } \\
\text { before vessel purchase }\end{array}$ & 4238 & cont & 17.753 & 9.59 \\
\hline B_AGE & $\begin{array}{l}\text { Age of the buyer of the } \\
\text { vessel }\end{array}$ & 4042 & cont & 36.412 & 9.045 \\
\hline B_S_SAME_REG & $\begin{array}{l}\text { Buyer has lives in the same } \\
\text { geographic region as the } \\
\text { seller of the vessel }\end{array}$ & 4238 & $0=$ no & 0.665 & 0.472 \\
\hline VESSEL_AGE & Age of the purchased vessel & 4238 & cont & 19.41 & 9.16 \\
\hline VESSEL_LEN & $\begin{array}{l}\text { Length of the purchased } \\
\text { vessel }\end{array}$ & 4238 & cont & $1,056.36$ & 415.50 \\
\hline PRICE_EURO_Def & $\begin{array}{l}\text { Price paid for the purchased } \\
\text { vessel (in } 2010 \text { Euro prices) }\end{array}$ & 4238 & cont & 144,199 & 184,997 \\
\hline B_REG_AQ & Buyer region is Aquitaine & 291 & $\begin{array}{l}1 \text { = yes, } \\
0=\text { no }\end{array}$ & $\begin{array}{l}6.86 \% \text { of } \\
\text { total }\end{array}$ & \\
\hline B_REG_NB & $\begin{array}{l}\text { Buyer region is North } \\
\text { Bretagne }\end{array}$ & 934 & $\begin{array}{l}1=\text { yes, } \\
0=\text { no }\end{array}$ & $\begin{array}{l}22.04 \% \text { of } \\
\text { total }\end{array}$ & \\
\hline B_REG_PL & $\begin{array}{l}\text { Buyer region is Pays de la } \\
\text { Loire }\end{array}$ & 723 & $\begin{array}{l}1=\text { yes, } \\
0=\text { no }\end{array}$ & $\begin{array}{l}17.06 \% \text { of } \\
\text { total }\end{array}$ & \\
\hline \# VESSEL_kW & The $\mathrm{kW}$ of the vessel & 4238 & cont & 134.41 & 105.59 \\
\hline \# B_FAM_TRADE & $\begin{array}{l}\text { Trade is between family } \\
\text { members }\end{array}$ & 4238 & $\begin{array}{l}1=\text { yes, } \\
0=\text { no }\end{array}$ & 0.025 & 0.155 \\
\hline \# S_PERM-EXIT & $\begin{array}{l}\text { The seller is permanently } \\
\text { exiting the fishery }\end{array}$ & 4238 & $\begin{array}{l}1=\text { yes } \\
0=\text { no }\end{array}$ & 0.0878 & 0.283 \\
\hline
\end{tabular}


* Variable means for continuous variables taken where $\mathrm{x}>0$. Averages are for the all transactions between 1992 and 2010.

\# Non significant variable 


\section{Table 3}

Network variables names and statistics for first time buyers and (for comparison) sellers in the second hand vessel trade network.

\begin{tabular}{|c|c|c|c|c|c|c|c|}
\hline Variable name & Description & $\begin{array}{l}\text { Sample } \\
\text { mean - } \\
\text { buyers }\end{array}$ & $\begin{array}{l}\text { Sample mean } \\
\text { - sellers } \\
\text { (for } \\
\text { comparison) }\end{array}$ & $\overline{\text { SD }}$ & skewness & Min & $\overline{\mathbf{M a x}}$ \\
\hline B_NW_ClC & Closeness centrality & 0.328 & 0.587 & 0.38 & 0.766 & 0 & 1 \\
\hline \multirow{2}{*}{ B_NW_CC } & Clustering & & & & & & \\
\hline & coefficient & 0.001 & 0.001 & 0.019 & 23.075 & 0 & 0.5 \\
\hline B_NW_ECC & Eccentricity & 3.421 & 5.622 & 6.036 & 2.532 & 0 & 30 \\
\hline$\overline{\text { B_NW_EDG }}$ & Edge Count & 2.804 & 2.714 & 2.397 & 2.733 & 1 & 17 \\
\hline B_NW_InD & In degree & 1.798 & 1.006 & 1.408 & 3.691 & 1 & 13 \\
\hline B_NW_OutD & Out degree & 1.006 & 1.709 & 1.198 & 1.674 & 0 & 7 \\
\hline & Neighbourhood & & & & & & \\
\hline B_NW_NHCon & Connectivity & 2.711 & 2.693 & 1.799 & 2.481 & 1 & 17 \\
\hline
\end{tabular}


Table 4: First time entry model through second hand vessel purchases.

\begin{tabular}{|c|c|c|c|c|c|c|c|}
\hline Variable name & Estimate & SE & t-ratio & $\begin{array}{l}\text { p- } \\
\text { value }\end{array}$ & $\begin{array}{l}\text { Odds } \\
\text { ratio }\end{array}$ & upper & lower \\
\hline \multicolumn{8}{|l|}{$1^{\text {st }}$ time buyer variables } \\
\hline B_YRININDUST & -0.068 & 0.028 & -2.390 & 0.017 & 0.935 & 0.988 & 0.884 \\
\hline B_AGE & -3.624 & 1.364 & -2.658 & 0.008 & 0.027 & 0.386 & 0.002 \\
\hline B_YRININDUST*B_AGE & 0.002 & 0.001 & 2.428 & 0.015 & 1.002 & 1.003 & 1.000 \\
\hline B_AGE*B_AGE & 0.003 & 0.001 & 5.450 & 0.000 & 1.003 & 1.005 & 1.002 \\
\hline \multicolumn{8}{|l|}{ Geographic variables } \\
\hline B_REG_SUBDI\$_AQ & -0.277 & 0.156 & -1.772 & 0.076 & 0.758 & 1.03 & 0.558 \\
\hline B_REG_SUBDI\$_NB & 0.300 & 0.095 & 3.173 & 0.002 & 1.351 & 1.626 & 1.122 \\
\hline B_REG_SUBDI\$_PL & -0.224 & 0.104 & -2.149 & 0.032 & 0.799 & 0.981 & 0.651 \\
\hline B_S_SAME_REG & 0.435 & 0.089 & 4.878 & 0.000 & 1.545 & 1.84 & 1.297 \\
\hline \multicolumn{8}{|l|}{ Vessel \& price variables } \\
\hline VESSEL_AGE & 0.027 & 0.013 & 2.060 & 0.039 & 1.027 & 1.053 & 1.001 \\
\hline VESSEL_AGE* VESSEL_LEN & 0.000 & 0.000 & -3.994 & 0.000 & 1.000 & 1.000 & 1.000 \\
\hline VESSEL_LEN* VESSEL_LEN & 0.000 & 0.000 & 6.619 & 0.000 & 1.000 & 1.000 & 1.000 \\
\hline PR_EUR000_DE & -0.004 & 0.000 & -8.616 & 0.000 & 0.996 & 0.997 & 0.995 \\
\hline \multicolumn{8}{|l|}{ Trade network variables } \\
\hline B_NW_ClC & -0.440 & 0.143 & -3.077 & 0.002 & 0.644 & 0.852 & 0.487 \\
\hline B_NW_ECC & -0.027 & 0.010 & -2.682 & 0.007 & 0.973 & 0.993 & 0.955 \\
\hline$\overline{B \_N W \_E D G}$ & -0.716 & 0.059 & -12.178 & 0.000 & 0.489 & 0.549 & 0.436 \\
\hline CONSTANT & 145.626 & 56.834 & 2.562 & 0.01 & & & \\
\hline
\end{tabular}

Model statistics: Log Likelihood of constants only model $=\mathrm{LL}(0)=-2795.267,2 *(\mathrm{LL}(\mathrm{N})-\mathrm{LL}(0))=$ 2068.534 with 19 df Chi-sq p-value = 0.000,

Note: for variables with correlation coefficients greater than 0.500 an interaction term was included. Interactions significant at the $5 \%$ level are shown in the table. 